\title{
FEVER PATHOLOGY IN THE SIXTEENTH CENTURY: TRADITION AND INNOVATION
}

\author{
by
}

\author{
IAIN M. LONIE*
}

\section{INTRODUCTION}

THIS PAPER is offered as a preliminary survey of mainstream writing about the pathology of fever in the sixteenth century. It is selective in the writers discussed, and confined to three topics: the definition of fever and febrile heat, the explanation of intermittent fevers, and the role of putrefaction. ${ }^{1}$ The paper is partly concerned with the relation between tradition and innovation. From this point of view, the writers discussed under the three topics listed above have their places along a descending scale of orthodoxy.

Both in form and content, sixteenth-century discussion of fever tends to be a prolongation of medieval discussion. It is not characterized by any notable rejection of the authority either of Avicenna or of Galen, nor by any significant tendency to apply new observation to traditional theories. As might be expected, ${ }^{2}$ the sixteenth century presents a picture of pathology rather different from the one which it presents in anatomy. Radical new approaches to the topic of fever did not occur until the following century, when they were prompted partly by the development of Paracelsian ideas, and partly by Harvey's discovery of the circulation. ${ }^{3}$ On the other hand, these changes in approach were not without anticipation in the sixteenth century, as the examples of Jean Fernel and Gomez Pereira will show. Of these two men, the one rejected the scholastic tradition, and the other vigorously defended it; but neither can be understood without an appreciation of that tradition. In fever literature it appears as a series of conventional quaestiones or problems, with approved strategies for their solution. These quaestiones had been generated, during the medieval period, by discrepancies and silences in Galen's account of fever. Most sixteenth-century writers simply followed the routine lines established by their predecessors. But the existence of such quaestiones, and the cryptic nature of Galen's account, left the traditional

\footnotetext{
* Iain M. Lonie, M.A., Wellcome Unit for the History of Medicine, Free School Lane, Cambridge CB2 3RF.

${ }^{1}$ Thus it does not include taxonomy, therapy, or the discussion of pestilence. Inclusion of this last topic (where the ancient tradition was singularly unhelpful) would have given a very different picture; but it is a subject in its own right, distinct from that of fever, while the topics discussed in this paper are an indispensable background to plague literature.

${ }^{2}$ See O. Temkin, Galenism, Ithaca, N.Y., and London, Cornell University Press, 1973, ch. 4, e.g. p. 152 and p. 165.

${ }^{3}$ See Audrey B. Davis, Circulation physiology and medical chemistry in England 1650-1680, Kansas, Coronado Press, 1973.
} 
theory somewhat open-ended even for the most conventional, while some writers were ready to exploit this fact in novel directions. This is clearest in Fernel's discussion of intermittent fevers and in Pereira's conception of febrile heat as the effect, and not the cause, of the accelerated motion of the heart and arteries. But even with the nature of fever, where discussion tends to be most conventional, we can detect a new emphasis on the concept of innate heat, although this arises quite naturally from the tradition.

The texts referred to in this survey were not written in a vacuum, but for the most part in response to pedagogical obligations. The topic of fevers was an important part of university courses in practical medicine. The prescribed text was usually the first fen of the fourth book of Avicenna's Canon, and lectures on fever most commonly took the form of a commentary upon this text, as they had in the medieval period. Avicenna might be supplemented by Galen's De febrium differentiis, and some teachers preferred to lecture on this text, with reference to Avicenna.4 Even when the course did not take the form of a commentary, as in various "Arts" or "Methods" of practical medicine, it nevertheless tended to follow Avicenna's order of topics, dealing first with the definition and essence of fever, then with the differentiation of fevers into their three main types (ephemeral, humoral, and hectic), followed by an exposition of the causes, diagnosis, and treatment of each type and sub-type. Besides these teaching texts, there were less formal genres in which fever might be discussed: collections of controversiae, paradoxa, and medical epistles. These were new genres, prompted by the invention of printing, as was the separate monograph or tract in which an individual point of view might be expressed and addressed to the indeterminate audience created by printing. Finally, there were the many collections of medical observations and consilia published during the century, in which fever cases were frequently included. While these often discussed theoretical matters, they generally confirmed traditional diagnosis and traditional taxonomy: the latter provided a convenient principle of arrangement. ${ }^{s}$

\section{THE DEFINITION OF FEVER}

It was generally agreed by sixteenth-century writers on fever, as by their predecessors, that the nature of fever lay in the "heat contrary to nature" or preternatural heat experienced by the patient. Almost all of them regarded this heat as a

\footnotetext{
4Among authors of commentaries or virtual commentaries may be mentioned Argenterio (1592); Massaria (1601); Trincavelli (1586); Valles (1569); Vega (1576). Trincavelli, lecturing on the text of Galen, assured his students that his comments were applicable to the corresponding loci in Avicenna, which they presumably had before them (p. 18). This is at Padua. Massaria, also at Padua (in 1587) lectured on the text of Avicenna, but said that since Avicenna was a more obscure author than Galen, his policy would be to explain Avicenna by reference to Galen. Argenterio, despite strictures on the uselessness of teaching by commentary, did claim to follow Avicenna's order closely (De febribus liber, Proem).

${ }^{3}$ E.g., Foreest ( 1586 etc.), who arranged his observations according to the traditional classification of fevers, linking classes with transitional types (a feature of Galen's approach to diagnosis) and he preceded each main group with an orthodox disquisition on symptoms, causes, and some discussion of quaestiones. Thus his work reads like a treatise on fevers very fully illustrated by textbook examples of each kind and variation. Since some were taken word for word from fifteenth-century writers of Practica, we may be suspicious of the originality of Foreest's observations.

The same approach to arrangement was adopted by Jodocus Lommius, Medicinalium observationum libri tres, Antwerp, G. Sylvius, 1560.
} 


\section{Fever pathology in the sixteenth century: tradition and innovation}

distinct kind or genus of heat, contrasted with other kinds. The most important of these was "innate" or "natural" heat: this was characteristic of the living animal and enabled it to perform its natural functions. Unnatural, preternatural, or febrile heat (the terms are interchangeable) was also called "extraneous" heat, i.e. extraneous or foreign to the living animal, as opposed to its own innate heat. ${ }^{6}$ In the account which follows, the fundamental opposition is between febrile (preternatural, unnatural, extraneous) heat and innate (natural, animal) heat. We should recall that heat was regarded as a substance, which was capable of division into different genera and species. This view followed naturally from a cosmology which regarded heat or "the hot" as one of the four elements of which all things, both animate and inanimate, are composed.

Galen had left no clear and unambiguous definition of fever. In De febrium differentiis, which assumed in the reader knowledge of much previous discussion by other writers now lost, he took the definition for granted, saying only that fever belonged in the genus of heat contrary to nature. Late Alexandrian writers, however, constructed a compendious definition out of scattered statements in Galen, and in this they were followed by the Arabs, notably by Avicenna. Avicenna's definition became the standard one for discussion: "Fever is extraneous heat, kindled in the heart, from which it is diffused to the whole body through the arteries and veins, by means of the spirit and the blood, reaching a heat in the body itself which is sufficient to injure the natural functions".?

Averroes, however, had given an alternative formulation: according to him fever was not merely extraneous heat, but must be to some extent natural or native heat, and was in fact a unity composed of natural and extraneous heat. ${ }^{8}$ This formula was modelled upon an incidental remark by Galen in his commentary upon the Aphorisms of Hippocrates: "fever occurs through the conversion of innate heat to the fiery".

This disparity between Avicenna and Averroes set the terms for all subsequent discussion, which pivoted on the relation between the preternatural heat of fever and natural heat. The implications of this debate, and the kind of argument with which it

\footnotetext{
'calor extraneus was the standard translation of the Greek thermotēs allotria ('foreign' or 'alien' heat) used both by Aristotle and Galen. This term appears to have been adopted into the discussion of fever from the Aristotelian Meteorologica 4, where it was used in the explanation of putrescence (sēpsis). Putrescence was there defined as "the destruction of a moist body's own natural heat by heat external to it, that is, the heat of the environment.' (Meteor. 4,1. 397al7; trans. H. D. P. Lee). Since at least some fevers were supposed to be caused by putrid humours (see section III of this paper), this became a key text in medieval and Renaissance fever literature; and the term "extraneous heat" conveyed to those who used it a distinct opposition to natural heat.

${ }^{7}$ Avicenna IV, I, i, I (1658). Avicenna's definition appears to be drawn from pseudo-Alexander Aphrodisiensis, De febribus 2 (1, 82 Ideler).

${ }^{8}$ Averroes iii, 3; vii, 2. In the first passage Averroes said that while the heat which injures the functions must be extraneous heat, it cannot be like the heat observed in dead (and putrefying) bodies, since it "manages" or concocts the humours, and is capable of becoming healthy. Therefore it must be a natural heat, though mixed with some quality of putrid heat. Moreover, since its subject is the heart, it cannot be entirely extraneous. Hence his definition of fever was "heat composed both of natural and of extraneous and putrid heat, sent from the heart to the whole body, and which injures all the body's actions and passions.... It is a transformation of natural heat in quantity and in quality, performing non-natural functions in the body ...".

$917 / 2,414$ and $426 \mathrm{Kühn;} \mathrm{cf.} \mathrm{15,} 456$ Kühn.
} 
was conducted, were conveniently indicated by Daniel Sennert (1572-1637), writing in the seventeenth century and reviewing previous discussion. Sennert recognized many diverse positions on the relation between preternatural and natural heat, but discussed only two. The first view was that in the fevered subject there are two distinct kinds of heat, natural and preternatural. These are distinct in species and do not become one: preternatural heat is superadded to natural heat, and it alone causes injury to the natural functions. The justification for this view is that natural and unnatural heat have different effects, natural heat assisting the works of nature, and unnatural heat opposing them. Since the physician must aim at removing unnatural heat, he would also have to remove natural heat along with it if the two were a unity. To cure the fever would therefore kill the patient. The other view was that fever is a composite of natural and unnatural heat. This is supported by the logical consideration that two accidents of the same species cannot be present simultaneously in one fever, and natural and unnatural heat belong to the same species, since both are overcome by one and the same contrary (Sennert presumably meant that the composite is a new form distinct from either component).

Sennert's own solution to the dilemma was characteristic of the level of sixteenthcentury discussion. He distinguished between natural heat (calidum nativum) and hotness (caliditas): the former is a substance and the latter a quality. Natural heat preserves its nature and functions in fever, but natural hotness combines with preternatural hotness to form a unity, and the hot distemper which is fever is composed from both. Formally it is all preternatural and febrile; but materially it is not wholly preternatural. Fever's injury to function is caused by the excessive degree of heat arising from the combination. The physician's task does not require the destruction of natural heat, only the removal of its excessive degree. ${ }^{10}$

In effect, almost all sixteenth-century writers arrived at this solution. It was not new, having been proposed around the end of the thirteenth century by Pietro d'Abano, ${ }^{11}$ and no doubt by others as well. Moreover, the terms in which the problem was set predetermined its solution: febrile and natural heat had to be distinct and opposed substances, since they were contrary in their effects; but equally, some formula had to be found for their combination, since the fevered patient presented one heat, not two. The solution of the problem in dialectical terms was an enterprise in which sixteenth-century writers invested a great deal of time and energy, each claiming, as commentators upon a traditional crux will, the merit of originality for his solution. While such originality was not usually sought outside the traditional terms of the problem, the writers discussed below attempted to clarify the concept of innate heat, and to use it to further their understanding of febrile heat.

Donato Antonio Altomare (1506-1562) was a professed Galenist ${ }^{12}$ who taught at

${ }^{10}$ Sennert (1627) I, i, 4-9.

"Pietro d'Abano (1526), Diff. 87.

${ }^{12}$ In the preface to the Opera omnia Altomare said that any who contradicted what they found there "should know that it is not I whom they will be contradicting, but Galen, with whom I would rather err than think rightly according to the mind of others." He added that many who had studied under him in' Naples would be able to testify to their progress in understanding Galen's doctrine. In his text he sedulously referred to Galen at every point. 


\section{Fever pathology in the sixteenth century: tradition and innovation}

Naples and subsequently at Rome. His tract De medendis febribus ars medica was published in both Naples (in 1554) and Venice (1562 and 1569), and also with editions of his collected works from 1565. The work originated as a course of lectures for students in practical medicine: these were not a commentary upon Avicenna but, as the title indicates, an "art" or "method", whose aim was the correct diagnosis and treatment of fevers. The layout was traditional, dealing in turn with the nature of fever, the differentiation of fevers, and the three main genera: ephemeral, putrid and hectic fevers. The whole was preceded by an elaborate discussion of method, and its application to the topic of fever.

A later contemporary, Orazio Augenio (c. 1527-1603), described Altomare as the first to introduce the idea that the subject of fever was the innate heat, rather than the heart or the whole body, ${ }^{13}$ and Alessandro Massaria (1510-1598) called this view a "novelty". ${ }^{14}$ Yet Altomare was not remarkable for his originality, and his choice of innate heat arose out of a rather commonplace attempt to reconcile Avicenna's and Averroes' definitions of fever with that of Galen. There are, he said, ${ }^{15}$ according to Hippocrates and Galen, two kinds of heat in the body, innate and acquired. The substance of innate heat is blood and semen, and it is aery and watery, while acquired heat is earthy and fiery. Acquired heat increases with age, there being a greater proportion of innate to acquired heat in the young, and of acquired to in nate heat in the old. ${ }^{16}$ Is this acquired heat the same as fever, which Galen said is the conversion of innate heat to the fiery? Yes, but it differs from febrile heat in degree and in cause. The relation of acquired to innate heat is that of an accident inhering in a substance: hence we avoid any difficulty about two opposed qualities, innate heat and febrile heat, inhering in the same substance, the body. ${ }^{17}$ The innate heat, in which fever inheres as an accident, must therefore be the subject of fever - not the heart, or the spirits, humours and solid substance of the whole body. Innate heat, not the heart, undergoes the conversion into the fiery which Galen said that fever is. But the source of the innate heat being the heart, we can also say that the heat of fever is generated in the heart. Moreover, the substance of the heart is composed of spirits, humours, and flesh, all of which are ultimately formed from blood and semen, or the innate heat. ${ }^{18}$ Since these three substances, spirits, humours, and flesh, jointly compose the substance of innate heat, they produce the three genera of fever, ephemeral, putrid or humoral and hectic. The rest of his discussion was divided according to these three genera.

This strategy is characteristic of sixteenth-century approaches to fever. However writers might vary in their solutions to the traditional problem of the nature of fever, a criterion of successful solution was that the traditional tripartite division should follow from the definition. That there were three basic kinds of fever was regarded as a matter of observed fact, independent of theories about the cause and nature of fever. Any theory which conflicted with this observed fact was bound to be wrong. For

\footnotetext{
${ }^{13}$ Augenio (1605), 53.

14 Massaria (1642), 318B.

15 Altomare (1565), cap. vii, 710.

${ }^{16}$ Ibid., ix, 712.

${ }^{17}$ Ibid., $x, 714$.

18 Ibid., xi, 716.
} 


\section{Iain M. Lonie}

example, the Spanish physician Francisco de Valles (1524-1592) in his Controversiae medicae developed the thesis that the subject of fever is the solid substance of the heart, because the humours and spirits are not animate bodies, and therefore cannot be subjects of disease. He recognized that this destroys the whole basis of the tripartite division of fevers, but argued that it should nevertheless he retained since, however unsound philosophically, it was indispensable for practice. ${ }^{19}$ Valles's pragmatism caused some scandal. Vittore Trincavelli (1496-1563) ${ }^{19}$ a replied that "knowledge does not create its own objects, but depends for its existence upon the existence of things themselves". ${ }^{20}$ Trincavelli's attitude helped to explain the painful care with which definitions of fever were constructed, and defended against every possible objection.

Altomare's view that the subject of fever is innate heat resulted directly from meditation on Galen's description of fever as occurring through the conversion of innate heat to the fiery. The context of Galen's remark was his commentary on Aphorisms 1.14, ${ }^{21}$ and much of what Altomare said paraphrased Galen's statements about innate and acquired heat in that passage. It is, therefore, perhaps fortuitous that, around the time at which Altomare was writing, a new emphasis was being given to the concept of innate heat in physiology by Jean Fernel (1497-1558). Altomare's book on fever was published in the same year as Fernel's Medicina (1554); he might, however, have become acquainted with Fernel's views on innate heat either through their early statement in De naturali parte medicinae (published in Paris in 1542, then in Venice in 1547, and in Lyons in 1551), or through De abditis rerum causis (1548). But if he was, he made no mention of them.

They were, however, adduced by an admirer of Fernel, Orazio Augenio. Augenio, writing between 1568 and 1572, attacked Altomare for making the innate heat the subject of fever, and referred in his arguments to Fernel's view that the innate heat was not a substance, but the form and soul of the body. It could not, therefore, be the subject of fever. ${ }^{22}$ Fernel himself did not entertain unprofitable and scholastic contro-

\footnotetext{
19 Valles (1556) v, cap. 18.

${ }^{19 a}$ The date of 1568 for Trincavelli's death given in the standard biographical and bibliographical sources must be altered to 1563 (personal communication from Richard Palmer, 1981).

${ }^{20}$ Trincavelli (1586), 7D.

${ }^{21} 17 / 2,404-415 \mathrm{Kühn}$. Since this was a crucial text in fever theory, both before and after Altomare, it will be helpful to the reader to summarize it here. Commenting upon the Hippocratic aphorism "Growing creatures have most innate heat etc.", Galen said that Hippocrates was referring to the substance of innate heat, not to its quality. Growing things have more of the substance, but they are not any hotter, just as a vessel which contains twice as much warm water than another is not thereby hotter $(407 ;$ cf. De temperamentis, I,554 Kühn: both texts were generally familiar). The substance of innate heat is aery and watery, deriving these qualities from sperm and menstrual blood respectively. As the body grows older, the proportion of earthy substance in it increases, so that even when it becomes very dry and fiery, despite this increase in heat the substance of innate heat which the body contains is very small. Otherwise we should have to say that in fevers the innate heat increases, whereas in fact it decreases in fever, the greater heat being provided by acquired heat, which is dry and fiery (408). Galen recurred to fever in commenting upon the latter part of the aphorism ("the fevers of old men are less acute than others, for the body is cold"). Galen said that this is because fever comes about through conversion of innate heat to the fiery $(413$; cf. 426), and this conversion cannot occur in the old to an equal extent with the young, in whom the quantity of innate heat is greater.

The substantial nature of innate heat emerges very clearly from this passage. and the view that this substance is what changes into febrile heat results almost automatically from Galen's words.

${ }^{22}$ Augenio (1605), 53-56. Augenio's own position on this matter is difficult to locate. He rejected Altomare's view in favour of the view, which he ascribed (II, I, p. 41) to Fernel, that the subject of fever is
} 
versy about the nature of fever: such controversy was altogether foreign to his style. He did, however, say that natural and febrile heat were opposed; that natural heat consisted of "elemental" heat and innate heat; and that innate heat, "whose origin is from heaven", could never be perverted, although its life-supporting action could be opposed and inhibited, by febrile heat. He agreed that some fevers could arise through an increase in natural heat, but only of its elemental component: these were "simple" fevers, and included ephemeral fevers and fevers caused by effervescing blood without putrescence (synocha or "non-putrid synochus" in the jargon of the schools). The seat of all fevers was the heart, except for intermittent fevers. ${ }^{23}$

Fernel's conception of innate heat was incorporated into the discussion of the nature of fever by Luiz Mercado (1525?-1611), who taught at Valladolid and subsequently became physician to Philip II. ${ }^{24}$ Mercado stood at the extreme end of a tradition. His De febrium essentia, causis, differentiis, dignotione et curatione libri, published in his collected works, were probably his lectures, although common humanity causes one to hope that they were not. In this work he took account of every possible opinion on fever, relentlessly subdividing, providing argument and counter-argument, until his purpose seems to disappear beneath a canopy of baroque elaboration.

Mercado regarded Avicenna's definition as the best, because it took most account of the various remarks of Galen upon the subject; but his aim was to show that Avicenna's definition, if rightly understood, included that of Averroes as well. Averroes, said Mercado, described febrile heat as "branching" (ramificari) out of natural heat, a.description which Mercado found excellent: "To say that febrile heat branches from natural heat means that it takes its origin from natural heat both formally and materially, ... formally, by deprivation of the degree of natural heat, whence arises that degree of preternatural heat which constitutes the form of fever ... materially, ... since the material of innate heat stands in relation of potency to its preternaturality." 25 Mercado then explained his meaning: according to Averroes' con-

the solid body of the heart. However, there is nothing particularly novel about this view, which was a fairly easy deduction from certain of Galen's statements, and which was held by others, by Valles, for example. referred to above. Nor was it particularly characteristic of Fernel. Although Augenio followed Fernel in many respects, and expressed great admiration for him, he piqued himself upon his own originality: for example, he claimed to be the first to have seen that Galen distinguished between fever and unnatural heat as its proximate cause, and said that it is not fever as such but unnatural heat which resides in the humours and spirits (II, 4, pp. 50-52). On the question of where the humours putrefy, within or outside of the vessels, he carefully distinguished between his own view and those of Fernel and Argenterius respectively (V, 4, p. 176); in other matters, too, he was eager to engage in polemic and to claim uniqueness for his opinions. The historian Sprengel took Augenio at his own valuation, but an examination of the passages to which Sprengel referred does not support his judgment. What is interesting about Augenio is not that he was original but that he eagerly claimed to be. (Incidentally it should be noted by future historians that Sprengel was wrong in his startling statement that Augenio "regarded fever as a mere symptom" (Versuch einer pragmatischen Geschichte der Arzneikunde, vol. 3, 214, Halle, 1794). No one to my knowledge in the sixteenth century said that. In the passage to which Sprengel referred (III, 5, p. 94) Augenio simply defended Avicenna's (and Galen`s) division of fevers into essential and accidental or symptomatic.)

${ }^{23}$ Fernel (1610), Pathologia, iv, 1, 241-242.

${ }^{24}$ There is a posthumously published note by $\mathbf{M}$. Nierenstein on Mercado in J. Hist. Med., 1947, 2: 124-127, which gives some details about his career, life and works and comments upon his discovery of diphtheria. There is much material also in L. S. Granjel, La medicina Española renacentista. Salamanca, Ediciones Universidad de Salamanca, 1980; and in J. Riera, Vida y obra de Luis Mercado. Salamanca, Ediciones Universidad de Salamanca, 1968, esp. pp. 51-59 on fevers.

2s Mercado (1619), I, 282BC. 


\section{Iain M. Lonie}

ception, febrile heat was a unity, composed of matter and form; the matter, however, was not the material of innate heat itself, but the degree of that heat: "According to the intention of Averroes we must understand 'potentiality' in the sense of the degrees of pre-existing heat, while the actuality and form come through the degree of extraneous heat. Hence preternatural heat is called one and the same thing as native heat, because one thing is produced, which is the hot distemper of the heart reduced to one simple form." 26

These passages are fairly typical of Mercado's approach. They may be accidental to his style, which was particularly awkward, but they also suggest that at this stage of its development the problem was beginning to generate an uneconomic amount of dialectical refinement. Mercado then asked after the precise nature of this pre-existing heat. which is changed to febrile heat. It is not sufficient to say "natural heat", since this has at least three senses, which Mercado expounded at length. The first sense is innate heat, properly so called. It is the heat which is present in semen and menstrual blood, but it also has a "celestial virtue", which enables it to compound and concoct the elements. The second sense is animal heat, whose source is in the heart, from which it is diffused over the whole body. It is not identical with the innate heat, but assists it in its operations. The third sense Mercado called "active heat". This is responsible for the temperature of the whole body, in which health consists, and which varies in degree from individual to individual according to his particular temperament. This kind of heat is composed of the heat in the solid parts, in the blood, and in the spirits; ultimately derived from the innate heat, it is not identical with it. This third kind of native heat becomes febrile heat by conversion to the fiery. ${ }^{27}$

Mercado asked whether the conversion of native to febrile heat is merely a change in degree from tempered to distempered, or whether the whole substance of native heat is altered as well. He contrasted the change from health to fever with the change in temperature supposed to occur as children grow to maturity. Here native heat is partly replaced by what is called acquired heat, native heat being moist and aery, acquired heat being dry and fiery. But the change from childhood to maturity does not entail any weakening or injury in the natural functions, whereas the change from natural to febrile heat does. This, said Mercado, is because the first is a change in degree only, while the second is a change in the substance of natural heat as well. Now the substance of natural heat is either the spirits, the humours, or the solid parts. ${ }^{28}$ From this position, Mercado could argue that there are three basic forms of fever, ephemeral, humoral, and hectic, according to whether the mutation occurs in the spirituous, humoral or solid substance of innate heat.

In effect, Mercado restated the position of Altomare that the subject of fever is innate heat, but he also accounted for Fernel's objection that any increase in the intensity of innate heat could only be beneficial and life-enhancing. Cumbrous as Mercado's restatement was, it genuinely attempted to understand the nature of febrile heat, and Mercado's debt to Fernel was direct.

\footnotetext{
26 Ibid., 282D.

27 Ibid., 284A-285F.

28 Ibid., 286A, 287C-F.
} 
We find the same emphasis on the role of innate heat as the subject of fever in Andrea Cesalpino (1519-1603), who discussed the problem in the Quaestiones medicae which he included in the second edition of the Quaestiones peripateticae published in 1593. Cesalpino's discussion was sensible and clear. Febrile and natural heat are indeed opposed, since fever injures the functions, not enhances them. Febrile heat increases the degree of natural heat, by destroying the quality of coldness which tempers natural heat and maintains health. There is a constant struggle between natural and febrile heat, each prevailing over the other in turn, the natural heat striving to concoct the febrile matter, and the febrile heat increasing its putridity. Although fever arises, as Galen said, by the conversion of innate heat to the fiery, this conversion is not complete, otherwise any fever would destroy life. Since febrile and innate heat act upon each other as contraries, they cannot be a unity as Averroes supposed: they inhere in the same subject, but in different parts of the same subject, the innate heat in the depths of the body and febrile heat nearer the surface. Nevertheless, since the substance of innate heat exists everywhere in the body, it is truer to say that the subject of fever is innate heat, rather than the heart which is merely its source. The substance of innate heat is composed of the spirits, the humours, and the solids, so it follows that there are three basic genera of fevers, according to which of these is affected. ${ }^{29}$

Mercado's discussion illustrates how any refinement in the concept of fever was made to depend upon refinements in the concept of innate heat. This is also true for later writers. Throughout the history of fever theory we can trace a systematic coordination between concepts of animal and of febrile heat. Where animal heat, in the seventeenth century, was explained as the consequence of fermentative processes, the heat of fever was explained in the same way, as by Thomas Willis. ${ }^{30}$ Or where animal heat was explained as the consequence of attrition, as the blood is forced through progressively narrowing vessels, the heat of fever received the same explanation in mechanist theories. ${ }^{31}$ Changes in view about the nature of fever came about through

\footnotetext{
${ }^{29}$ Cesalpino (1593), Quaest. med. I, v-vi; cf. Cesalpino (1605), Lib. ii, cap. ii-iv, pp. 42-52, where there are some differences.

${ }^{30}$ Diatribae duo ... (London, 1659), De febribus, ch. 2: "Therefore Motion and Heat in the Blood, depend chiefly on two things, viz., partly on its own proper disposition and constitution by which, it being forged very greatly with active principles of Spirits, Salt, and Sulphur, of its own accord swells up ... and partly on the Ferment implanted in the heart, which very much rarefies the Liquor passing through its bosom, and makes it to leap forth with a frothy heat ..." (trans. S. Pordage, Works, London, T. Dring, 1684 , p. 54). The heat of fever is given a similar explanation: fever is "a Fermentation or immoderate Heat, brought into the Blood and Humours ... it is only the Bloud (with the Nervous Liquor, the alible Juice and Serum Associates) which boiling up above measure, with its heat, and stirred up with a rage through the Vessels diffuses the preternatural heat ..." (ibid., pp. 47-48). In the De sanguinis accensione, however, which was published in 1670, Willis offered a different explanation of animal heat. Here it is a kind of burning in the blood, fuelled by sulphur, which Willis specifically distinguished from fermentation.

${ }^{31}$ The mechanist explanation of animal heat by attrition was expressed most clearly by Archibald Pitcairne (1652-1713): "the heat of the blood may be considered as a rectangle under the velocity and the distance" (quoted by E. Mendelsohn, Heat and life, Cambridge, Massachusetts, Harvard University Press, 1964, p. 69, from Archibald Pitcairne, The philosophical and mathematical elements of physick, trans. J. Quincy, 2nd ed. London, 1745, pp. 21-23). The attrition explanation was applied both to natural and to febrile heat by Borelli: the vehement motion of the heart is the efficient cause of the body's heat, which is an effect, not a cause, both in fever and in the healthy state. This heat is produced not by motion as such, but either by attrition which releases the aetherial particles of the blood from their bonds, or by mixture with
} 
changes in physiological theory: consequently, the terms in which fever was discussed, and the kind of evidence appealed to, were determined by the categories and evidence used in basic physiological explanations. For the sixteenth-century writers whom I have been examining, both febrile and innate heat were active substances, whose understanding depended upon logical analysis. But post-Harveian writers regarded febrile heat as an effect, whose causes could profitably be examined while its precise nature was left unspecified. The approach of Mercado and others simply became antiquated. This change in fashion was, of course, due to a broad range of circumstances, although in the particular case of fever theory, Harvey's discovery of the circulation was crucial. Yet as the example of Gomez Pereira will show (pp. 39-43), such a new perspective on the nature of fever was perfectly possible in the sixteenth century, and within the confines of the scholastic tradition.

\section{INTERMITTENT FEVERS: FERNEL}

Although discussion of the nature of fevers remained within the medieval framework, Jean Fernel significantly modified the traditional doctrine of intermittent fevers. His modifications were prompted by medieval debates, but their direction was determined by Fernel's novel approach to general pathology.

In taxonomy, the recognition of intermittent fevers as a distinct type would appear to be basic, a first-order distinction, and on the whole this was true of seventeenth- and eighteenth-century writers. In Galen and the medieval tradition, however, it was only a secondary distinction within the genus of putrid humoral fevers. ${ }^{32}$ The distinction was also obscured because Galen regarded all putrid fevers, continuous as well as intermittent, as showing a periodic pattern. Galen was emphatic that what he called the "form" or "idea" of each type of humoral fever was determined by its particular humour. The good diagnostician will recognize this form from a number of factors, of which the pattern of intermission or remission was only one. ${ }^{33}$ Putrid fevers were caused by yellow and black bile, and phlegm: there were therefore three kinds, each of which could appear in two forms. A tertian, for example, could be continuous, with a three-day cycle of remittance, or truly intermittent, with complete disappearance of febrile symptoms between each attack. This account, although clearly it originated from the striking phenomenon of intermittence, tended to lessen the significance of

lixivial salts in the viscera, to which the motion of the heart impels the blood (De motu animalium, II, (Rome, 1681), prop. ccxxv, 460-465). An explanation similar to Borelli's was adopted by Boerhaave, both for animal heat and for febrile heat. For the former see Institutiones medicae, 5th ed. Leiden, 1734, $\S 968$; Aphorisms $\$ 100$ with van Swieten's commentary (in Hermanni Boerhaave Aphorismos commentaria, I, pp. 142-145, Leiden, 1745) and Praelectiones academicae. Amsterdam, 1742, II, p. 297. For the heat of fever, see Aphorisms $\$ \S 673-689$, especially $\S \S 675-676$; also $§ 580$ and $\S 581$.

${ }^{32}$ In De crisibus 2, 6 Galen said that continuous and intermittent fevers are of the same genus (homogeneis), continuous tertian being correlated with intermittent tertian, and so on (9.662 Kühn; cf. De febrium differentiis 2, 2. 7, 336-338 Kühn). For the medieval tradition, the classification given in the Philonium of Valesco de Taranta (fl. 1382-1418) is typical: he divided humoral fevers into four (the first being caused by blood), then each of these was divided into a continuous and an intermittent form, according to whether the humour putrefies within or outside the veins (De febribus cap. 1, in De febribus opus sane aureum.... Venice, apud Gratiosum Perchacinum, 1576, 254r-v).

${ }^{33}$ De crisibus 2, 9 (9,677, 15-17; 683, 10-684, $\left.18 \mathrm{Kühn}\right)$; cf. De febrium differentiis 1, 13 (7, 329. 14-330, 5 Kühn). 


\section{Fever pathology in the sixteenth century: tradition and innovation}

that phenomenon in relation to others, such as the shuddering (rigor) which was particularly characteristic of tertians. Galen's pathological explanation was designed to explain shuddering as well as intermission.

The basic feature of this explanation was that the temporal discontinuity of the fever is correlated with a spatial discontinuity of the humours in the body. Both the fits of shivering and the period of the onsets were accounted for by quanta of putrid humours moving from one part of the body to another. These quanta accumulated, putrefied, and were expelled in periods of time which differed according to the quantity and quality of the particular humour. Galen associated this process of periodic accumulation and expulsion with the "disposition" (diathesis) of the part which expelled, or attracted, the humour. But Galen was notably vague about what parts he meant. ${ }^{34}$

This explanation was generally agreed by subsequent writers to be the least satisfactory part of Galen's account of fevers. Controversy arose over two points: the place where the humours putrefied, and Galen's failure to account for the regularity of pattern in intermittents by the variables of quantity and quality in the humours.

On the first point, medieval writers, both Arabic and Latin, seem to have been satisfied with a simple formulation: in continuous fevers the putrid humours were contained "within the vessels" (intra vasa), while in intermittent fevers the putrid humours were "outside the vessels" (extra vasa). The ambiguities covered by this convenient formula were immediately exposed when writers attempted to give a more detailed account. Did Galen mean that humours first putrefy within the vessels, from which they are then expelled, or did he mean that they putrefy outside the vessels altogether, and if so, where?

The controversy over the second point was clearly described by Cesalpino:

The aforesaid intermissions do not seem to occur by reason of expulsion. For what stimulates expulsion is a harmful quantity or quality. Now yellow bile has a quality which is more irritating than the other humours, namely a mordant acridity and bitterness. Therefore this humour should be the quickest to accumulate, and after it, black bile, while phlegm should be the slowest of all to accumulate. But we find just the opposite occurring in the periods. If on the other hand we consider the quantity of each humour, since this will vary according to age, constitution, season, region, diet and other factors of this kind, there will be a similar variation in the periods. But in fact we see that the same periods are perpetually maintained for each humour, whatever the season, age etc. ... Nor can we explain by reason of attraction. A thin humour is attracted more quickly than a thick. Yet phlegm, though it is thicker than yellow bile, completes its period more rapidly. ${ }^{35}$

As Cesalpino here indicated, what struck observers was the precise regularity of intermittents, which was independent of age, constitution, diet, and all other variables. Galen's inability to account for this precision gave rise to a regularly debated quaestio on which there were two well-defined positions. Either the explanation was sought in astronomy, or it was referred to an "occult cause". The first was particularly associated with Pietro d'Abano (1250-1315?), who expounded it in his 88th Differentia. In the circumstances of the time, it was perhaps the most reasonable one to adopt: here was a case in which a pathological phenomenon seemed to share the

\footnotetext{
${ }^{34}$ Galen, De febrium differentiis 2, 13-18 (7, 338-405 Kühn).

${ }^{35}$ Cesalpino (1593), Quaest. med. I, x, 190v.
} 
mathematical regularity associated with celestial phenomena. A similar instance was that of critical days, and there was warrant in Galen for associating this with the moon. ${ }^{36}$ Yet writers were generally sceptical of the astronomical explanation. The alternative explanation, proposed by Gentile da Foligno (d. 1348) and Tommaso del Garbo (d. 1370), was open to the objection that if the cause was occult, "it could contribute nothing either to our knowledge of fever or to its cure". ${ }^{37}$ Moreover, the word "occult" had disagreeable associations.

The real difficulty, to which these explanations bear witness, lay in the inadequacy of humoral pathology to explain diseases presenting an unvarying clinical pattern, and best accounted for by an ontological theory of disease. Intermittent fevers were potentially subversive of humoral theory. This is illustrated by the remarks of an eighteenth-century writer, Gerard van Swieten: "I must confess myself utterly unable to conceive how any fomes or irritating matter should be collected in the body in a certain space of time so as to excite the fits regularly. ... It seems hardly credible that morbid humours should be collected precisely in the same intervals of time, in so many patients differing in age, sex, etc. ..." 38 Van Swieten then suggested that there must be some specific cause, an "epidemical character" or "impression" concealed in the nervous spirits. For such an "impression" he referred to the Archeus of Helmont, and indeed there is a direct line from Fernel through Helmont to van Swieten. Van Swieten's suggestion is all the more interesting in that he remained loyal to the humoralism of Boerhaave.

Fernel's theory of intermittent fevers was cautiously sketched in De abditis rerum causis (1548) in the protective colouring of the literary dialogue, then with more emphasis and precision six years later in the Medicina. In this latter work he began by referring to the medieval discussion:

There is an old opinion which by now has become popular, that the humour which is the sustaining and proximate cause of intermittent fever grows putrid in the habit of the body and outside the veins. At the beginning of the accession this humour is driven out from the greater veins, in which it was concealed and mixed with the blood, into the smaller veins, and from these into the habit of the body. This impulsion causes the peripheral parts of the body, which are more highly sensitive, to grow chill and shiver at the contact of the humour as it strikes them. The humour in its turn gradually grows warm, is inflamed, and putrefies; eventually it is rarefied by the heat and wholly dissipated in sweats. Thus the accession comes to an end, and another recurs in the same manner. But this opinion, although it attempts with some plausibility to explain chill and rigor, obscures the true origin of intermittent fevers. ${ }^{39}$

Fernel presented various objections to this theory. The imagined process would take too long, whereas the onset of fever is sudden. It did not sufficiently differentiate between intermittent and continuous fevers, some of which also begin with shivering. It was incompatibie with what was actually observed in the course of intermittent fevers, in which all symptoms were more violent at the onset, and milder in the declination, when bile appeared in the urine - a sign that it was at the end, rather than

\footnotetext{
${ }^{36}$ On this, see Andrew Wear, 'Galen in the Renaissance', in Vivian Nutton (editor), Galen: problems and prospects, London, Wellcome Institute for the History of Medicine, 1981.

${ }^{37}$ Mercado (1619), 311.

${ }^{38}$ Van Swieten, vol. 2 (1749), 537, commenting on aphorism 757 . The whole comment states very clearly the problems caused by intermittent fevers.

${ }^{39}$ Fernel (1610), Pathologia IV, ix, p. 251.
} 


\section{Fever pathology in the sixteenth century: tradition and innovation}

at the beginning, that the humour was expelled to the periphery. Finally, if it were true, venesection at the beginning should prevent the fever, but this is not the case.

These objections cleared the ground for Fernel's own theory, which he introduced with a modest apology for departing from a view sanctified by so many years and so many authors. The material of intermittent fevers does not grow putrid in the periphery of the body; nor is this material the juice contained in the veins, the function of which is to nourish, but superfluous humours. "Thus intermittent fever is distinguished from continuous fever both in its material and in the site and focus of that material." 40 The matter of a tertian is yellow bile, akin to that which is secreted in the gall-bladder; of a quartan, black bile which accumulates in the spleen; of a quotidian, superfluous phlegm collected in the stomach and intestines. "Of all these fevers the proper seat and origin is in the first region (prima regio) of the body, in the hypochondrium, the stomach, the diaphragm, the concavities of the liver, the spleen, pancreas, or mesentery. These parts form the public cesspool or bilges of the body, in which the offscourings of the humours all gather and collect."41 Fernel then explained that the praecordia is one of the most sensitive regions of the body, since it receives the sensory nerves which come from the sixth conjugation of the brain. It also has a sympathetic connexion with other parts of the body, as is shown by the phenomena of chill and shivering; and it is the source of sweating. In a word, all the symptoms of intermittent fevers could be explained, and associated with the anatomical facts, much better by Fernel's theory than by the one which he had rejected. The putrescent humour gives off a putrid vapour: this "strikes" (ferire) the sensitive membranes of the diaphragm and produces chill and shivering. The vapour also travels to the heart "by hidden ways", and from the heart it is distributed over the body through the arteries. Hence changes in the pulse, stupor, headache, and lassitude. At length the vapour becomes rarefied and is expelled in sweat and insensible perspiration. Finally, Fernel appealed to post-mortem dissection to confirm his theory: "When the body was opened we discovered the cause of all these affections: pure bile of the green variety around the concavities of the liver, held in by the membranes, to the weight of $1 \mathrm{lb}$; a portion of it had also crept into the nerves of the spine." 42

Although Fernel apologized for the novelty of his theory, it was in fact constructed out of traditional elements; and in the sketch of it in De abditis rerum causis, he attributed it to Galen, from whom he cited the following passage: "A quotidian hardly ever occurs without an affection of the cardiac orifice, just as a quartan is associated with an affection of the spleen, and a tertian, of the liver." 43 Nevertheless, it struck contemporaries as novel; and the real originality of Fernel's solution of this traditional quaestio can be seen if we place it against the background of his general pathological

\footnotetext{
40 Ibid., p. 252.

${ }^{41}$ Ibid. This passage was noted by C. A. Wunderlich, in his classic paper on fever ('Das Fieber. Historisch-physiologische Untersuchungen', Archiv f. physiologische Heilkunde, 1842, 1: 266-294, p. 275). Wunderlich also truly observed of Fernel as well as of Paracelsus that both were less concerned with the concept of fever as such than with the processes which cause and accompany fever (ibid.). I am grateful to Walter Pagel for drawing my attention to this study.

42 Fernel, op. cit., note 39 above, p. 254.

${ }^{43}$ De abditis rerum causis (1610), II, xiii, 115; Galen, De methodo medendi ad Glauconem 1, 5 (11, 18 Kühn).
} 
theory. In a passage of the Pathologia, Fernel stated that the contenta of the body (spirits, humours, and excrements) were never the subject of disease, but only its causes: diseases themselves were to be located in the parts of the body, and symptoms in the functions:

We do not call affections of the spirits or humours or excrements diseases, even when they are contrary to nature, since these do not inhere in the parts. It is only a bad disposition of the parts which is a disease: a bad disposition of the humours or spirits is the cause of disease. Neither do the humours, when they putrefy in the veins, bring disease or injure the function, until they touch the effective parts with contagion (contagione attingant) and injure them. It is in this way that intermittent fever, the falling sickness, hydrophobia and many other diseases maintain their cause within quietly and inertly during an interval, so that this cause does not excite the disease except when it provokes the parts. ${ }^{.4}$

In the next century, van Helmont saw and clearly expressed the significance of Fernel's theory:

Fernel was the first to expose the ignorance of the Schools, whence Rondelet and the Galenists attacked him as a deserter and apostate. He was the first to sniff out the nest of intermittents, which is around the stomach, duodenum, and pancreas; and he placed the seat of the continuous fevers around the heart. Yet he did not dare to depart from the old rules for curing fevers. For though he began by maintaining the nest of fevers in open dispute against the Schools, he ended by concealing himself in hidden causes. Unable to free himself from the straw bonds of putrid fevers, he allowed the understanding of the essence of fevers to be wrested from his grasp. ${ }^{45}$

Helmont's assessment is entirely just. What made Fernel's view capable of further development is that by focusing attention on the prima regio, it introduced into fever theory an explicit connexion with anatomy. It thus prepared the way for the application of the detailed anatomical investigations of the next century to the pathology of fever. Furthermore, Fernel's theory contributed to a growing emphasis in taxonomy on the distinction between continuous and intermittent fevers. Above all, it seemed to recognize the inadequacies of the humoral explanation of intermittents, and the need for an ontological explanation. Yet his confinement by the straw bonds of humoralism is illustrated by his explanation of the periodicity of intermittents - although here too Fernel pointed forward in an interesting way.

In De abditis rerum causis, what he said about intermittents arose from a more general discussion of epidemic diseases, in which he believed that there was "something occult". This was also true of intermittent fevers. They could not be explained by putrescence of humours alone. Fernel had observed a case of quartan fever in which the putrescence was removed, and yet the quartan remained. From this, and many other similar considerations, "we may understand that its proximate cause is not in obstruction or the putrescence of humours, but in some hidden affection which inheres in the parts." 46 This, Fernel claimed, was the opinion of Galen in De febrium differentiis, written in his old age: Galen said that intermittents continued to recur so long as the disposition was preserved in the parts generating the disease. Fernel here explicitly rejected the humoral explanation of intermittent fevers as arising from a dyscrasia or distemper of the humours: "this disposition is altogether different from a

\footnotetext{
4 Fernel (1610), Pathologia 1, iii, 181. See Antoinette Stettler, 'Jean Fernel, Felix Platter, und die Begrundung der modernen pathologischen Theorie', Gesnerus, 1977, 34 : 340.

${ }^{45}$ Helmont (1667), De febribus 3, 80 .

${ }^{46}$ Fernel (1610), De abditis rerum causis II, xiii, 114.
} 
distemper (intemperies)". Fernel then outlined his view of the seat of intermittents.

Here the disposition which caused the recurrence, the "occult cause", was located in the part. But in the section on fevers in the Pathologia, Fernel located it not in the part but in the humours themselves. Intermittent fevers, he said, are like epilepsy or hydrophobia, where there is a similar regularity of recurrence. ( $\mathrm{Cf}$. the passage from the Pathologia cited above.) This is caused, not by the genus of the humour but by "the nature of the quality implanted in the humour. ... So too a certain power (vis) or quality generated in the humour brings it about that phlegm attacks by putrefying every day, yellow bile on the third day, and black bile on the fourth." 47 Superfluous humour accumulates "until it can no longer be governed by nature or natural heat. It grows corrupt and putrid, and then at last it acquires that quality, which has this or that motion and impetus. And as each humour has its own species, so each has its own kind of putrefaction and its own kind of motion." 48 While formally consistent with what Fernel said in the Pathologia about the causation of disease, this cannot be reconciled with his statement in De abditis rerum causis, that the cause is in the disposition of the part, not in the putrescence of the humour. ${ }^{49}$

However, what Fernel said about putrescence pointed forward to theories about fermentation. It was a part of Fernel's explanation that the "quality" in the putrid humour is acquired in the process of corruption: it is not present, in actuality, in the humour from the start. This was made explicit by Fernel's follower, Augenio, who said that the explanation lay not in the quantity or quality of the humours, but in "the peculiar condition of their putrescence". This, he said, is a kind of property inseparable from the humours themselves, as the property of being able to laugh is inseparable from the essence of man. It may be called a specific form, or even an occult property, like the attractive power of the lodestone. ${ }^{30}$ Fernel's view was similarly described by Daniel Sennert. Sennert noted that the occult quality is generated by the putrescence itself; if present in the humour from the start, it would be destroyed in the process of corruption. ${ }^{\mathbf{3 1}}$

Sennert's own view may have been prompted by that of Fernel. After reviewing past and current theories about intermittents, including Fernel's, he said that a satisfactory account could be extracted from Galen. Galen was correct in suggesting that the cause of intermittence lay in the nature of the humour. But Sennert's strategy was to say, first, that this nature is acquired in the process of putrefaction, as Fernel did; and, second, to identify putrefaction with the process of "effervescence and fermentation". Galen had said that intermittents recurred because after one accession, there is a "putrescent residue" (sēpedonōdes perittōma) left over. Sennert promptly identified this residue with a ferment: "According to the nature of that miasma, or putrid residue or, to put it plainly, ferment, so too the humour which causes the paroxysm

${ }^{47}$ Fernel (1610), Pathologia IV, xi, 255.

48 Ibid.

49 The contradiction was remarked by Guillaume de Baillou, De virginum et mulierum morbis liber, iv, ed. M. J. Thévart, Paris, 1643 (vol. 4, 23 in the Venice, 1736 edition of de Baillou's Opera omnia medica).

${ }^{\text {so }}$ Augenio (1605), p. 188.

s1 Sennert (1627), II, xvi, p. 422. 


\section{Iain M. Lonie}

begins to effervesce and putrefy more rapidly or more slowly."\$2 He noted that different substances have by nature differing periods of fermentation; and so it is, he said, with the humours. Sennert thus brought fermentation into the explanation of intermittent fevers, another indication of how increased emphasis on their peculiar nature was important in the development of fever pathology. Sennert, however, did not develop this suggestion, but typically attempted to combine it with the Galenic explanation by the quantity and quality of the humours. Thus longer paroxysms are caused either by a greater quantity of the offending humour, or by a greater crassness in its composition.

Fernel's original reference to an occult cause in intermittent fevers arose within the context of a discussion of epidemic and pestilential fevers. Such diseases were often explained by a "miasma" of particularly venomous nature. A "venom" or poison was thought to account for the sudden prostration characteristic of pestilence, and also for its rapid course, where the concept of a large quantity of humour, which would take time to accumulate, was of no help. These somewhat vague concepts of miasma, venom, and - as Sennert's substitution of terms in the passage above indicates ferment, were all related. One direction in which Fernel's account of intermittents pointed is illustrated by the seventeenth-century writer, Richard Morton. Morton's definition of intermittent fever read: "Intermittent fever is preternatural heat, kindled in the blood by an unusual expansion of the spirits ... recurring in fixed periods according to the genius of the venom which is its efficient cause." 53 Morton admitted that he could not explain what this venom is, because it escapes the senses. (This was Fernel's occult cause.) But we can deduce its real existence from its effects. He later substituted the term miasma for venenum, suggesting that it must be treated by an antidote which will be, in most cases, the bark.

Fernel's originality lies in his critical attitude to tradition and readiness to survey it anew. Thus his theory about intermittents derived from his general theory of pathology, a field in which his originality has recently been indicated by Antoinette Stettler. ${ }^{54}$ In this respect he fits our stereotype of the Renaissance scientist - just as he does in the appeal which he makes to observation, including post-mortem observation, in establishing his theory. The old theory is at variance with the facts, so a new one must be found, based on unprejudiced observation. Fernel's observational arguments sharply contrast with the a priori arguments used to discuss the nature of fever, a discussion which Fernel avoided. However, observational arguments in the debate about intermittent fevers were traditional, since the various theories proposed about these fevers were causal ones, established by and intended to account for the symptoms of intermittents. ${ }^{55}$ In other respects, too, we must be cautious in the degree of originality

\footnotetext{
32 Ibid., p. 434.

\$3 Morton (1696), Exercitatio I, cap. iii, 'De febre intermittente', 42. However, in Morton's theory, venom is not peculiar to intermittents but is present in all acute fevers.

s4 Fernel, op. cit., note 44 above, pp. 333-341.

ss Thus Augenio, introducing his discussion of where the humours putrefy in intermittent fevers, said that in this matter we must argue a posteriori from effects to causes. In the passage which follows, Augenio referred to observed facts such as the occurrence of rigor and chills in intermittents, vomiting, the appearance of the urine at the beginning of the accession, which testifies that there is no bile present in it as
} 


\section{Fever pathology in the sixteenth century: tradition and innovation}

with which we credit Fernel. His account of fever as a whole, including taxonomy, pathology, and therapy, was very traditional in content. Any novelty which it had apart from the matter of intermittents - lies in the elegance of style and the clarity of presentation. For example, his classification of fevers was a tidier version of that implicit in Galen and the medieval tradition, rather than a basically new taxonomy. ${ }^{56}$ Elegance and clarity of style are not unimportant; in combination with other factors, they go a long way towards accounting for Fernel's considerable influence upon contemporary and later writers. But in Fernel's general theory of fevers, the clarity was gained rather by cutting away and discarding the complexities of medieval discussion than by offering a radically new approach. Such an approach was offered by Gomez Pereira, whose style had no elegance at all, and who until recently was hardly noticed by historians. ${ }^{57}$

\section{PUTREFACTION, HETERODOXY, AND GOMEZ PEREIRA}

Gomez Pereira (born c. 1500) may be considered with a number of writers who explicitly attacked Galenic orthodoxy. The avowal of such an intention is not uncommon in the introductions to sixteenth-century texts: it has something of the conventional about it, and it could be furnished with commonplaces about truth, authority, and progress which flowed comfortably from the pen. The real test of claims to question established authority lay in the amount of traditional doctrine which a writer was prepared to sacrifice. In a sense, almost all sixteenth-century writers on fever were orthodox, since the tradition permitted considerable variation in detail. Van Helmont's treatise on fevers, first published in 1642, provides a useful contrast. In it, Helmont launched a witty and devastating attack upon the doctrine that fevers were caused by the putrefaction of humours. This attack was three-pronged, involving the rejection of the Galenic concept of febrile heat, of putrefaction as a major cause of fevers, and of humoral pathology. Helmont was not interested in the Galenic classification, and he regarded traditional therapies of purging and bleeding as pernicious as well as mistaken. Helmont could afford to be radical, since he attacked Galenism from the basis of an alternative pathology.

The most enduring component of the Galenic system was the belief that a large variety of fevers were caused by the decomposition, or putrefaction, of the humours.

yet $(\mathrm{V}, \mathrm{iv}, 170-172)$. The systematic relation of these and other symptoms to the topic discussed was drawn by Augenio from various passages in Galen, whose interpretation of their relevance Augenio accepted without question.

${ }^{36}$ Fernel (1610), Pathologia IV, ii, 242-243.

${ }^{57}$ Felix Platter (1536-1614) should be mentioned here as an independent thinker who was nevertheless much influenced by Fernel in his theory of fevers. Platter in De febribus liber (Frankfurt, Wechel, 1597) disregarded discussion of the nature of fever, as Fernel did; his general division of fevers by essential differences in febrile heat was Fernel's, whom Platter quoted several times. The differences in heat must be differences felt by the patient, the basis of Platter's nosology. Continuous and intermittent fevers are caused by putrefaction of blood: the only humour which putrefies is excrementitious bile, which infects the blood. Intermittents are caused by putrid blood in the mesaraic veins, but Platter denied Fernel's "hidden passages" to the heart. Platter denied the existence of quotidians; he also proposed the original view that some inflammations are pyrogenic, caused by fever instead of producing fever as in Galen's theory. Platter's classification of fever was part of his general classification of diseases: it contained some new elements but many old ones as well. 
This was still very much alive in the system of Boerhaave, who explained it in terms of alcalescence; it was accepted by many eighteenth-century writers; and the term "putrid" as a description of certain kinds of fever survived humoralism. Putrescence was a conveniently vague concept which satisfied several needs at once. It provided a radical degenerative process in the body to explain the origin of fever; its presence seemed to be attested by offensively foetid excreta; and it provided a plausible link between pathological processes and environmental factors, such as putrid exhalations from swamps, which seemed to be causally associated with fevers. It also agreed with the not unnatural belief that fevers might be caused by eating "bad" food, and it maintained belief in the value of traditional therapies, particularly purging. ${ }^{58}$

On the other hand, there were certain difficulties with the concept. Putrefaction was associated with dead rather than with living bodies; it seemed to be an irreversible process; and the notion that humours, and especially the blood, carrier of life, could as it were "die" while still in their natural place in the vessels of the living body, was objectionable to some. ${ }^{39}$ The objection had already been made in antiquity, according to a passage in Alexander of Tralles (6th century A.D.) which was regularly cited in fever literature: some held that fevers are caused by "burning" (ustio) of the humours, not their putrefaction. For if humours grow putrid in the vessels, we should find evidence of putrefaction, such as maggots, in the urine, but this is not the case. ${ }^{60}$ This passage gave warrant to later writers for attacking the doctrine of putrefaction.

One of these was Laurent Joubert (1529-1583), in his Paradoxorum decas prima atque altera (1566). In the preface to this work Joubert aligned himself with those who were fearless in questioning received opinion: men such as Argenterius, Fernel, and especially Joubert's own teacher Rondelet. Earlier in the preface, Joubert had suggested that many useful doctrines were proposed in antiquity, but were suppressed by the envy of later men: the fragmentary remains of the Greek philosophers show this to have been the case. Galen, for example, meanly attributed to other authors anything in Hippocrates which he found uncongenial: even those doctrines which he did accept he treated as a nose of wax, to be twisted to any shape which he thought fit. Some of Hippocrates' teaching he merely ignored: thus Hippocrates held a doctrine about the material and the seat of fever, which is unknown today because Galen made no use of it.

Accordingly, Joubert set out to demolish Galen's explanation of putrid fevers, and to substitute the Hippocratic explanation. The title of Paradox II, 2 reads: "That no fevers, especially those which are salubrious, arise from putrescent humours, but rather from those which are effervescent or burnt'. Joubert began by pointing to a vagueness in Galen's statements about putrefaction: Galen, he said, confused the very different concepts of putrescence, effervescence, and inflammation. There is no reason why humours which are enclosed in an ample space, and in their natural locus, should

s8 $\mathrm{Cf}$. Sennert (1627), II, i, 88-89, where some of these reasons are stated.

${ }^{59} \mathrm{Cf}$. Boerhaave, Aphorisms $\S 730$ : "But the term putrid in this fever has been offensive to many, who have judged it hard that the humours should putrefy in a body yet living. But ... the ancient physicians did not understand such a corruption as we observe to arrive spontaneously in dead bodies, but only a considerable degeneration from their natural and healthy condition."

${ }^{60}$ Alexander Trallianus (1556), XII, ii, 684-685. 
ever grow putrid. Blood does not putrefy while it is in the blood vessels: it is therefore unlikely that the humours of which the blood is composed do so either. This is confirmed by observation: putridity is accompanied by a foul smell, but the humours have no such smell in fever. It is not putrefaction which causes fever, but ebullition, or burning. Joubert developed this statement in the next paradox. Hippocrates said that most fevers are caused by bile. In fact, they all are: for bile, being volatile and oily, is the most combustible of all the humours. In this and the next paradox, Joubert expounded a fever pathology which relied heavily upon a crude analogy between combustion and fever. Bile is the fuel of fever, and it produces heat and smoky vapours by burning, just as oil or wood does. The varying symptoms of different types of fever are to be explained by variation in quality of the bile which serves as a fuel. The seat of fever is the heart, and the vessels proximate to it: these can contain a sufficient amount of bile, which burns with less intensity than other fuels, so that a little of it goes a long way. The heart is the seat of intermittent as well as continuous fevers: hence Fernel was mistaken on this point, as Joubert elaborately demonstrated. To explain the shuddering characteristic of intermittents, Joubert adopted the explanation given in the Hippocratic texts Breaths and Diseases 1. He quoted extensively from these texts, and also from Diseases 4 , which contained a combustion theory of fever. ${ }^{61}$ Finally he congratulated himself on the agreement between his own view of fever, and that which was held by the father of medicine. ${ }^{62}$ This self-congratulation is a little disingenuous, since Joubert's theory was constructed entirely out of these Hippocratic passages.

Joubert's views were restated by the Italian philosopher and physician Simone Simoni (1532-1602), in a work entitled Synopsis brevissima novae theoriae de humoralium febrium natura, published in Leipzig in 1577. Like Joubert, Simoni represented himself as a bold critic of established opinion. In his address to the reader, Simoni said that he had long doubted the established doctrine of fever, particularly the intermittents. In 1558 he heard Cardan lecture on the subject at Pavia, and communicated these doubts to him: "But he, being (as I learned some years later) a man able to ingest a great deal more than he could digest, used to convey me up on each of my visits into a third heaven of wonder and delight. But he never actually told me anything which had much bearing on the subject in question."

Simoni then returned to Padua, where he heard Trincavelli lecture on fevers, without receiving much enlightenment. However, his own careful observation of fever cases convinced him that in both intermittent and continuous fevers the traditional doctrine was in error in associating a particular type of fever with a particular humour: more than one humour might be active in each type. He also found not the slightest trace of putridity in fevers. From Italy he went to France, where he came across the work of Joubert. This at first excited, and then disappointed him: Joubert's reasoning was not solid enough, and confused as well. Hence Simoni had to evolve his own theory, which he then offered to the reader.

In fact, Simoni added little except detail to Joubert's statement. He repeated

${ }^{61}$ Diseases 1, 24-25 (VI 188, 14-192, 10 Littré); Breaths 8 (VI 100, 13-104, 3 Littré); Diseases 4, 46-53 (ed. R. Joly, Hippocrate, Tome xi, Paris, Les Belles Lettres, 1970, pp. 100-114).

62 Joubert (1566), II, ii-iv, pp. 331-413. 


\section{Iain M. Lonie}

Joubert's arguments against putrefaction, his theory of bile as the fuel of fever, which Simoni illustrated with the same Hippocratic passages as Joubert had cited, his belief that the heart is the seat of fever, and his arguments against Fernel. On other points, Simoni was orthodox. He retained the Galenic division of fevers into ephemeral, humoral, and hectic; more surprisingly, he retained the subdivision of humoral fevers into those which are caused by bile, phlegm, or blood, although this is a blatant contradiction of his hypothesis. He defended himself by saying "although bile is the humour most suitable for combustion, the other humours also become subjects of febrile heat by the admixture of bile." ${ }^{63}$ In fact Simoni was ambivalent on the role of the humours in fever. The liveliest part of his book is chapter v, in which he discussed the problem of intermittence. He rejected Fernel's explanation by occult causes: his attitude was that this and other problems arose only because each of the intermittents was traditionally associated with a particular humour. But this doctrine is contrary to reason, because it fails to explain the differing characteristics of intermittent fevers, and contrary to experience, because observation of intermittents shows that more than one humour may be present in each. The belief that the diverse periodic patterns of intermittents are to be explained by assigning a particular humour to each one is the greatest single cause of error and inconvenience in the whole practice of medicine. ${ }^{64}$ This statement looks like a radical rejection of Galenic theory, since Galen's discussion of humoral fevers was based on the principle that the form which each humoral fever presents to the diagnostician is to be explained by the particular humour which causes it. Yet Simoni himself insisted that the aim of diagnosis should be to determine which of the humours is active in a particular case of fever, and that treatment should be specifically directed against that humour. ${ }^{65}$

The performance of these self-styled critics of established doctrine was disappointing. Their criticisms were often captious, although there were many points in which Galen's doctrine of putrid fevers was highly vulnerable to a reasoned attack; and they have nothing substantial to offer in place of that doctrine. Joubert's account of fever appeared in the rudimentary form which it had in its Hippocratic sources, and he made no attempt to refine it or to support it with arguments. It is difficult to decide how seriously to take Joubert. Sprengel gave him a significant historical position along with Argenterius as one of the anti-traditionalist precursors of the coming revolution in medicine. ${ }^{66}$ Yet Joubert does not look like a revolutionary. He enjoyed a highly successful career as an academic (both Dean and Vice-Chancellor at Montpellier), as a courtier, and as a popular author in the vernacular. His Traite du ris (1579) and his Erreurs populaires (1578 and 1579) were best sellers, whose wit amused and agreeably scandalized the fashionable public. The Paradoxa themselves are in the form of medical epistles - a form which could, of course, have scientific as well as literary aims.

Simoni presents a similar ambiguity. His career suggests the tireless seeker after truth, religious as well as scientific. He was brought up as a Catholic, but became a

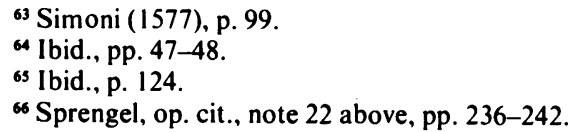


Calvinist. When Italy became too hot for him he went to Geneva in 1566, where he may have held the chair of medicine, and then to Paris, where he lectured on philosophy with great success, although he was attacked by the Sorbonne for referring to Thomas Aquinas without his saintly title. From Paris he went to Heidelberg, where he exchanged Calvin for Luther; he remained in Germany for ten years (1570-1580), which he spent at Leipzig. He then went to Prague, and there he was reconverted to Catholicism; he finished up in Cracow, as personal physician to King Stephen of Poland. ${ }^{67}$ The Synopsis was published during his stay in Leipzig, together with a tract defending Joubert's views on putrefaction against one Bruno Seidel, ${ }^{68}$ who had written against Joubert; Simoni in his turn was attacked for the same doctrine by Jakob Schegk (1511-1587). Intellectual restlessness, the temper of the times, above all the opportunities for gaining notoriety which were offered by the printed tract - all these are relevant factors in estimating the weight to be given to a particular scientific controversy, and the commitment of its protagonists. We should also note that in pathological theories sixteenth-century writers were prepared to tolerate a degree of vagueness and imprecision which would have been unacceptable a century later.

With Gomez Pereira we return to the question discussed in the first section of this paper, the nature of febrile heat. For Pereira's highly original and independent views on fever, including his rejection of the putrefaction theory, all derive from the position which he took on febrile heat. In the third chapter of his book, Novae veraeque medicinae experimentis et evidentibus rationibus comprobatae, prima pars (1558), he simply denied the assumption upon which all previous discussion of the nature of fever had been based. There is no specific difference between natural and preternatural heat; moreover, there are no specific differences within febrile heat itself, and the differences between fevers, so far as they are based on such specific differences, are imaginary. Pereira's attack was explicitly directed against Galen and the "sectatores Galeni".69 Among these he included Fernel, whose essentially Galenic classification was based on a distinction between simple, putrid, and malignant and pernicious febrile heat. Although Pereira retained the traditional classes of fever (ephemeral, putrid, and hectic), these distinctions were no longer of importance, since all fever is essentially one. Fever is an activity of that vital spirit which is peculiar to man, and is not shared by other animals.

Pereira defined fever as follows:

Fever in its essential nature is an immoderate heat which sensibly injures the functions in man. It is produced in the whole body by nature, who strives to bring it about by the most rapid and frequent impulsion of the blood and spirits from the heart into the arteries of the whole body, and the superheating of the heart by a rapid and frequent expansion and contraction, and also by the heat which is summoned from the swift motion of the arteries as they contract and expand. Nature produces fever to this

${ }^{67}$ For Simoni’s biography see G. Caturegli, Simone Simoni: medico insigne del secolo .rvi (Scientia veterum 147), Pisa, Casa Editrice Giardini, 1970; Eberhard Stübler. Geschichte der medizinischen Facultät der Universität Heidelberg 1386-1925, Heidelberg, Winter, 1926, pp. 56-57. An anonymous author remarked in 1588: "Simonius Lucensis primum Romanus, tum Calvianus, deinde Lutheranus, denuo Romanus, semper autem Atheus."

68 'Sententia Brunonis Seidelii de iis quae Laurentius Joubertus in Paradoxis suis de febrium humoralium origine ac materia disputavit', published in Laurent Joubert, Operum latinorum tomus primus, Frankfurt. Wechel, 1599.

${ }^{69}$ See, e.g., Pereira (1558), col. 84. 


\section{Iain M. Lonie}

end, that the superfluities which harmfully affect the human body may be dispelled, or concocted and expelled through the sensible passages of the body which are opened out by febrile heat, and that other damages to human nature may be repaired. ${ }^{70}$

Max Neuburger drew attention to the significance of Pereira's view of the depuratory and curative purpose of fever, and Walter Pagel has set him in a wider current of ideas which leads through Tomaso Campanella to Helmont. ${ }^{11}$ Pereira's originality also emerges when he is read against the background discussed in the first section of this paper. What is crucial is Pereira's idea, which he plainly stated in several passages, that febrile heat is not a substantial entity which acts as a cause, but is the effect of the accelerated motion of the heart and arteries: "The heart is impelled to increase its own heat, which it does in a wonderful manner and in no other way than by contracting and expanding more rapidly and more often than it was wont to do." 72 This accelerated motion is the response of the heart to a stimulus or irritation, which may arise in various ways. It may be caused by humour excessive in quantity, or noxious through corruption, which cannot be discharged from the body through the usual passages: in this case nature creates a fever to heat the humour and expel it in the form of vapours. ${ }^{73}$ Or it may be caused by a wound, which affects the heart so that "it is irritated (proritetur) and as it were pinched (vellicetur) into producing very rapid and frequent systole and diastole." 74 It is usually vapours such as those which arise from putrid humours which have this effect upon the heart. Unlike Joubert and Simoni, Pereira did not deny the putrefaction of humours. It was, however, essential to his conception of fever that febrile heat is not generated directly by putrefaction - there is no specific putrid heat - and he devoted a long chapter to the critique of Galen's doctrine on putrid fevers. Here he marshalled thirteen arguments against Galen. Most of these were based on observation, consistently with the title of Pereira's work, and their depth and trenchancy contrast with the superficiality of Joubert's approach. Pereira was remorseless in exposing the contradictions of Galen's account; he also revealed the weakness and vagueness of Galen's analogies, in a way which seems to anticipate Helmont's attack on this kind of argument. Putrefaction cannot possibly produce heat which is great enough to increase the heat of the heart itself. The vapours given off by putrid humours cannot be hotter than the humours themselves; and if they are hotter than the heart, how is it that we do not feel them before they have reached the heart? Obstruction and lack of ventilation cannot increase the temperature of the

\footnotetext{
70 Ibid.. 109.

$"$ Walter Pagel, New light on William Harvey, Basle, Karger, 1976, pp. 71-73 and notes (with references to Neuburger's two works). For Campanella, see also idem. 'Helmont. Leibniz. Stahl.' Sudhoffs Arch., 1931, 24: 37-38. I am grateful to Dr. Pagel for drawing my attention to Pereira and for discussing him with me. José Jimenez Girona, 'La esencia de la fiebre en Gomez Pereira', Asclepio, 1966-67, 18-19: 439-456, accurately summarizes Pereira’s doctrine. Pereira was virtually unnoticed by earlier historians, but he was mentioned by John Barker, An essay on the agreement betwixt ancient and modern phisicians. London, 1748, p. 164. Barker included him along with Vesalius. Argenterius, and Fernel among those who attacked Galen's authority. See also T. de Bordeu. Recherches sur l'histoire de la médecine, in Oeuvres, vol. 2. Paris, Caille \& Ravier, 1818, pp. 663-670. Cf. also José Jimenez Girona, 'Alguras noticias sobre la piretologia de Gómez Pereira’, Bol. Soc. españ. Hist. Med., 1968, 8: 7-13.

72 Pereira (1558), col. 111 ; see also 123 and 132.

73 Ibid., 111.

74 Ibid. 112-113: cf. 114-115.
} 


\section{Fever pathology in the sixteenth century: tradition and innovation}

source of heat, as Galen seemed to suppose with his analogies of enclosed bath-houses and the like: indeed these factors are more likely to extinguish the source of heat. If obstruction is the cause of putrid heat, then this is inconsistent with Galen's explanation of shivering, which he said is caused by the release of vapours. If putrescence is the cause, why is it that those who are on the point of death grow colder, when the putrescence is presumably at its height? Finally, Galen's theory is inconsistent with his physiology, in which he said that compression of the arteries expels vapours. How then could hot putrid vapours ever reach the heart in sufficient quantity to increase its heat? ${ }^{75}$

Pereira nevertheless retained the traditional putrid fevers as nosological descriptions; but he gave to the putrid humours the role of occasional causes ${ }^{76}$ - the essential cause is, as always, the accelerated motion of the heart and arteries. In the case of putrid fevers, this motion is the heart's response to the irritation of putrid vapours from the humours, which infect the blood. In intermittent fevers, the humours play a passive role: the periods of intermittents are explained by variation in the quantity and the sluggishness of individual humours, which allows them to resist the expulsive motion of the heart for shorter or longer periods. In quartan fevers for example, putrid atrabilious humour "annoys the heart by its vapours or by its substance, and compels it to those movements of contraction and dilatation which we have described, and which cause febrile heat powerful enough either to disperse the noxious vapours and the humour itself ... or to drive it so far from the heart that it causes the heart no annoyance, but leaves it in peace for a period of three days." 1 In quotidians on the other hand, phlegm being more viscous, heavier, and in greater quantity than black bile, cannot be driven so far from the heart, so that it returns to provoke a paroxysm every twenty-four hours.

Thus the features of Pereira's theory were that febrile heat is not specifically different from natural heat, but is an effect of the accelerated motion of the heart and arteries, this motion being provoked by a variety of causes, and its purpose being to separate and expel noxious substances from the blood. These features recurred in several theories of fever devised after Harvey's discovery of the circulation, with the purpose of accommodating that discovery.

Yet this novel theory was presented in very scholastic dress. The address to the reader which Pereira prefixed to his book was a bitter attack on Erasmian humanism. He presented his science in theological terms. His was a difficult task of attacking Galen and Aristotle, and fashionable doctrines. But he had "a burning desire to teach the truth, and to extirpate superstition from the schools of Europe." In reality it was not his own position which should cause wonder, but that of those who professed to teach dialectic, physics, theology, and medicine, but whose whole concern was in the pedantic knowledge of Greek, Latin, and Hebrew: who aimed at perfection in these languages, but had not so much as tasted the sciences which they were supposed to teach. Erasmus was the founder of their sect, who allured them from the arduous

\footnotetext{
75 Ibid., cap. vi, 59-103.

${ }^{76}$ Ibid., 142: "quarum (febrium) occasio est humor cholericus".

"Ibid., 144.
} 
discipline of logic and physics ${ }^{78}$ to humanistic studies, with a cunning like that of Mahomet - or Luther. Hence, among other evil consequences, the befouling of the text of Sacred Scripture. These men had turned the sciences of theology and medicine into grammar; and in approaching them, equipped only with linguistic skills, they were like cobblers and mechanics who read the Scriptures in the vernacular, and took it upon themselves to expound them. As for Pereira's criticism of Aristotle and Galen, this required no defence but rather congratulation. His predecessors and contemporaries had laboured to know and expound rather than to understand and critically examine the texts of these authors, which they treated like Delphic oracles.

In conformity with his defence of scholasticism, Pereira's discussion of febrile heat began with an examination of the views of Marsiglio di Santa Sophia, Gentile da Foligno, and Hugo of Siena. ${ }^{79}$ His discussion was conducted in scholastic terms, but this did not preclude an extensive use of observational arguments. He stated the principle that the ultimate criterion of heat is touch, and that experiment is the ultimate arbiter of truth: "So enormous is the force of experience in the discovery of the truth, that we must, when an apparent reason is opposed to experience, place greater trust in the experiment than in the reason, and search for a more powerful reason." ${ }^{80}$ Pereira singled out for attack the view of Gentile da Foligno, with which he later identified the view of Fernel, though he avoided naming the humanist writer. Gentile had said that not only do natural and preternatural heat differ specifically, but that there are specific differences within preternatural heat itself, from which the specific differences of fevers are derived. This was precisely Fernel's position, so it was a contemporary view that Pereira was examining. ${ }^{81}$ Pereira admitted that natural heat, which arises from the blood in the form of an exhalation or "spirituous body", may be overwhelmed by putrid vapours, or the humour which gives off these vapours may be overwhelmed by natural heat. But it does not follow that there are two kinds of heat which are opposed. Any specific difference will lie between the two bodies which are hot, and not between the kinds of heat which they produce. ${ }^{82}$ Touch, the sole criterion of heat, does not perceive any difference between the heat of a stone which is warmed by fire, and the heat of a stone which is warmed by the hand, although the former is preternatural and the latter natural heat ${ }^{83}$ Similarly, if you put your hand in water which is as warm as the heat of the body, you feel it as neither hot nor cold: yet some difference should be felt, if the natural heat of the body and the preternatural heat of the water are contraries. ${ }^{84}$ Pereira appealed to experiment in countering the argument that preternatural heat can extinguish natural heat, as one contrary

\footnotetext{
${ }^{78}$ Pereira meant the scholastic disciplines: we cannot read his attack on humanism as Baconıan. Later in the preface he said: "If my standing with Christian princes was great enough for them to listen to my advice, no one should graduate in the faculties of theology and medicine who had not sweated over the summulae for two years, and for as many over Physics, and over Logic for one year." On the other hand, we may legitimately compare him to Bacon in his emphasis on observation, both in the title and in the body of his text. But for Pereira observation could only be fruitful within the framework of Aristotelian logic.

${ }^{79}$ Pereira (1558), cols. 8-9.

80 Ibid.. 11 .

81 Ibid., 8, 10, 86-87, 91-94.

82 Ibid., 15-16.

83 Ibid., 21-23.

84 Ibid., 29.
} 
another, in the way that one flame sometimes appears to extinguish another. It is not, he said, the heat of the flame which does this, but its smoke. This can be demonstrated: if a small flame is placed vertically under a large one, the larger flame will be extinguished; place the two flames at an equal distance on the horizontal plane, and this will not happen. ${ }^{85}$

Such arguments may remind us of Francis Bacon, but the intellectual framework in which they were presented was scholastic, and Pereira also used a priori arguments derived from the concepts of substance and accident, just as Mercado and others did.

Yet Pereira's approach, and the original concept of fever which emerged from his discussion, sharply distinguished him from these writers. Pereira himself referred to Hugo of Siena as warrant for his belief in the specific unity of natural and preternatural heat. ${ }^{86}$ But Hugo himself merely offered a variant of Averroes' solution of the problematic relation between natural and preternatural heat. For him, as for all other medieval - and sixteenth-century - writers on fever, febrile heat was a substantial entity and a causal agent, not the consequence of physiological changes. It seems unlikely that this radical shift in perspective arose directly from the tradition of comment upon Galen and Avicenna. But to enquire into its source is outside the scope of this paper.

Note: This paper has been modified in the light of comments made at the seminar at which it was originally presented. I am particularly grateful to Dr. Andrew Wear of the University of Aberdeen for his painstaking and informed criticism of the original draft.

The work on which the paper is based was done during tenure of a Wellcome Research Fellowship in the History of Medicine.

\section{ORIGINAL SOURCES CITED}

Pietro d'Abano, Conciliator differentiarum, Venice, 1526.

Alexander Trallianus, Alexandri Tralliani medici libri duodecim ..., Joanne Guinterio Andernace interprete, Basle, per Henricum Petrum, 1556.

Donato Antonio Altomare, De medendis febribus ars medica, Naples, 1554 (Omnia, quae hucusque in lucem prodierunt, Lyons, Rouille, 1565).

Giovanni Argenterio, De febribus liber (Opera, Venice, Ciotti, 1592 (Hanover, 1610)).

Orazio Augenio, De febribus . . libri septem ... ab anno 1568 usque ad 1572 singuli conscripti, Frankfurt, heirs of A. Wechel, 1605.

Averroes, Colliget Libri VII, Venice, Junta, 1562.

Avicenna, Canon medicinae ... interprete et scholiaste ... Plempio, Tom. I, Louvain, 1658.

Andrea Cesalpino, Quaestionum medicarum libri II, Venice, Junta, 1593.

Andrea Cesalpino, Katoptron sive speculum artis medicae Hippocraticum, Frankfurt, Becher, 1605.

${ }^{85}$ Ibid., 14.

${ }^{86}$ Ibid., 9. 
Jean Fernel, De abditis rerum causis libri, II, Paris, C. Wechel, 1548 (Hanover, 1610).

Jean Fernel, Medicina, Paris, A. Wechel, 1554 (Hanover, 1610).

Pieter van Foreest, Observationum et curationum medicinalium libri tres . .., Leiden, Plantin, 1586 (Opera omnia, Rouen, 1653).

Galen, Claudii Galeni opera omnia, edited by C. G. Kühn, 22 vols., Leipzig, Cnobloch, 1821-1833.

J. B. van Helmont, De febribus (Ortus medicinae, Lyons, Huguetan, 1667).

Laurent Joubert, Paradoxorum decas prima atque altera, Lyons, Senneton frères, 1566.

Jodocus Lommius, Medicinalium observationum libri tres, Antwerp, G. Sylvius, 1560.

Alessandro Massaria, De febribus (Practica medica, Frankfurt, 1601 (Venice, 1642)).

Luiz Mercado, De febrium essentiis, causis, differentiis, dignotione et curatione, Valladolid, B.a sancto Dominico, 1586 (Opera, Frankfurt, 1619).

Richard Morton, Operum medicorum ... tomus secundus, Amsterdam, T. Donati, 1696.

Gomez Pereira, Novae veraeque medicinae experimentis et evidentibus rationibus confirmatae, prima pars, Medina del Campo, F.a Canto, 1558.

Felix Platter, De febribus liber, Frankfurt, Wechel, 1597.

Jakob Schegk, 'Confutatio erroris Simonis Simonii, quo contra Galenum sentiens, negat putridarum febrium causam esse putredinem humoris alicuius', in Tractationum physicarum et medicarum tomus. Frankfurt, J. Wechel, 1585.

Daniel Sennert, De febribus libri IV, Wittenburg, 1619 (Lyons, 1627).

Simone Simoni, Synopsis brevissima novae theoriae de humoralium febrium natura, Leipzig, 1577.

G. van Swieten, Commentaria in Hermanni Boerhaave aphorismos, 5 vols., Leiden, 1745-1772.

Vittore Trincavelli, In primum Galeni librum de differentiis febrium explanatio (Omnia opera, Lyons, Junta, 1586).

Francisco de Valles, Controversiarum medicarum et philosophicarum libri decem, Alcala, J. Brocar, 1556.

Francisco de Valles, Commentaria in libros Galeni de differentia febrium, Complutum, A. ab Angulo, 1569.

Cristobal de Vega, Commentaria in librum Galeni de differentiis febrium (Opera, Lyons, Rouille, 1576). 